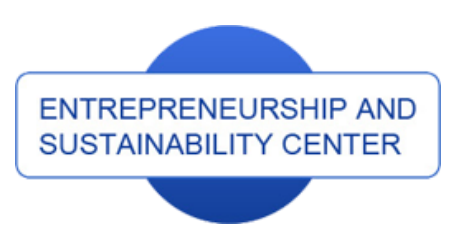

Publisher

http://jssidoi.org/esc/home enterprise

europe

network

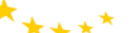

Business Support on Your Doorstep

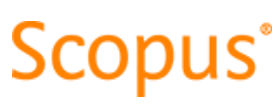

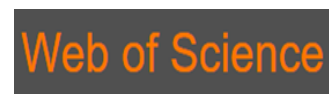

1 Clarivate

\title{
INTENTIONS TO ADOPT ECOPRENEURSHIP: MODERATING ROLE OF COLLECTIVISM AND ALTRUISM
}

\author{
Farida Saleem ${ }^{1}$, Ahmad Adeel ${ }^{2}$, Rizwan Ali ${ }^{3}$, Shabir Hyder ${ }^{4}$ \\ ${ }^{1,2}$ Lahore Business School, The University of Lahore, Gujrat Campus, Punjab, Pakistan \\ ${ }^{3}$ Lahore Business School, The University of Lahore, Lahore, Punjab, Pakistan \\ ${ }^{4}$ Department of Management Sciences, COMSATS Institute of Information Technology, Attock, Pakistan. \\ E-mails: ${ }^{1}$ farida.saleem@lbs.uol.edu.pk; ${ }^{2}$ ahmad.adeel@lbs.uol.edu.pk; ${ }^{3}$ rizwan.ali@lbs.uol.edu.pk , \\ hydershabir@ciit-attock.edu.pk
}

Received 15 April 2018; accepted 22 October 2018; published 30 December 2018

\begin{abstract}
There is a need to understand the importance of sustainability of economies by the students especially undergoing business education and look for avenues that provide support to sustainability, in which ecopreneurship is one. The current study examines the intentions to adopt ecopreneurship while extending the theory of planned behavior model by including the dual moderating role of collectivism and altruism while taking developing country context as a field of analysis. Data were collected from students of two universities located in a rural district and student participants of entrepreneurship training workshop. Results show that ecopreneurship is mainly driven by subjective norms and self-efficacy while attitude towards ecopreneurship become significant in presence of collectivism and altruism not otherwise. Similarly, the dual moderating role of collectivism and altruism has been identified by the significance of threeway interactions for attitude, subjective norms and self-efficacy with collectivism and altruism respectively.
\end{abstract}

Keywords: Sustainability; Ecopreneurship; Collectivism; Altruism; Theory of Planned Behavior

Reference to this paper should be made as follows: Saleem, F.; Adeel, A.; Rizwan Ali, Hyder, S. 2018. Intentions to adopt ecopreneurship: moderating role of collectivism and altruism, Entrepreneurship and Sustainability Issues 6(2): 517-537. http://doi.org/10.9770/jesi.2018.6.2(4)

JEL Classifications: Q56, L26, D64

\section{Introduction}

Since 1980's the word "Sustainable development" has been referred as buzz word (Tilley and Young, 2009). The most popular definition of sustainable development was given by World Commission on Environment and 


\section{The International Journal \\ ENTREPRENEURSHIP AND SUSTAINABILITY ISSUES}

ISSN 2345-0282 (online) http://jssidoi.org/jesi/ 2018 Volume 6 Number 2 (December) http://doi.org/10.9770/jesi.2018.6.2(4)

Development (WECD) (1987: 8) according to which sustainable development is "development that meets the needs of the present generation without compromising the ability of future generations to meet their own needs". This definition makes us answerable to the future generations about environment depredation. Business units are one of the major entities that have direct impact on the sustainable development. Due to the rise in awareness level, the general public is not only demanding eco-friendly products but also sustainable practices by their producers. The lack of participation of entrepreneurial new ventures in sustainable management can not only cause the specific country left behind on sustainable development but can further worsen the natural environmental conditions. The sustainable entrepreneurship, also called ecological entrepreneurship or ecopreneurship, can be taken as a possible way to address the problem of environmental degradation (Muñoz and Cohen, 2018; Law, Hills, and Hau, 2017; Keijzers, 2002). This type of entrepreneurial activity links business to the sustainability management. Taiwan, by putting focus on sustainable management has successfully generated both economic as well as social benefits for the whole community (Valdez-Juárez, García-Pérez-de-Lema, and Maldonado-Guzmán, 2018; Pfajfar and Mitręga, 2016; Chen and Jaw, 2009). The recycling system in Taiwan is the best example of how communities can get benefits from practicing sustainable management practices (Outsios and Kittler, 2017; Sardianou, Kostakis, Mitoula, Gkaragkani, Lalioti, and Theodoropoulou, 2016; Koe and Majid, 2014).

Considerable evidence exists among developed and developing countries about saving the environment and initiating the entrepreneurial activities targeted at saving the depleting environment (Canever, Barral and Ribeiro, 2017; Ozaralli and Rivenburgh, 2016; Gubik and Farkas, 2016). Entrepreneurship is a source of promoting employment and bringing prosperity to the economy (Iglesias-Sánchez, Jambrino-Maldonado, Velasco, and Kokash, 2016; Testa and Frascheri, 2015; Holmgren and From, 2005). Especially in the developing countries context the entrepreneurship is seen as a way to trigger economic development and to handle serious economic and social challenges, in this regard besides enhancing economic activity the protection of environment is a serious concern. The question like how to promote the eco-businesses is an evergreen challenge. This calls for highlighting the factors that influence the adoption of eco-entrepreneurship for sustainable future decisions. The economic growth with ecological friendly entrepreneurship has received attention in recent times (Mbebeb, 2012) and a positive attitude towards adoption of such entrepreneurship is found. Further, the significance of the concept, within the context of green economy, can be understood by the concept of ecological entrepreneurship that has emerged as means to decrease market failures and enhance social welfare through the exploration of environmentally responsible opportunities (Muñoz and Dimov, 2015; Miller, 2015; Meek, Pacheco, and York, 2010). According to Marsden and Smith (2005; p.440), "through a process which we call ecological entrepreneurship, key actors facilitate sustainable development in the countryside by a combination of fragmentation, specialisation and quality building strategies".

The researchers have recognized that there are chances that the intentions to initiate ecological entrepreneurial activities may be moderated by social, cultural, and ecological norms; it is at times influenced by economic interests that are characterized by patterns of aggressive and unsustainable consumption (Koe and Majid, 2014). The United Nations Organization (2011) has recognized eco-friendly entrepreneurship as an intervention strategy, a catalyst for fostering the process of economic development, and at the core of this action is the eco-entrepreneur. Thus, given the necessary drive, the entrepreneurs who have the intentions to start their businesses must consider investment in the ecological entrepreneurial opportunities at the first instance. Ecological entrepreneurship is one of the major drivers of green economy (Mbebeb, 2012). Schaltegger (2002) while coining the term ecopreneur identifies their unique role by stating that "whereas all entrepreneurs deal with bridging activities between suppliers and customers to create and change markets, ecopreneurs differ from conventional entrepreneurs in that they also build bridges between environmental progress and market success." (2002, p. 46). The environmental risks are translated into green business opportunities by ecological entrepreneurs. Similarly, they also respond to the negative consequences of businesses on the natural environment by introducing environmentally friendly 


\section{The International Journal}

ENTREPRENEURSHIP AND SUSTAINABILITY ISSUES

ISSN 2345-0282 (online) http://jssidoi.org/jesi/ 2018 Volume 6 Number 2 (December) http://doi.org/10.9770/jesi.2018.6.2(4)

products and processes (Gast, Gundolf, and Cesinger, 2017; Schaper, 2016; Pastakia, 2002). In the same run, Hill et al. (2010: p. 37) acknowledged the growing business viewpoint that "as pressure increases on the world's natural resources, concerns over environmental degradation have shifted from the fringes of altruistic concern to tangible global economic losses."While highlighting the importance of sustainable wealth creation Marsden and Smith (2004: p. 441) strongly recommended that in order to respond appropriately to emerging needs, "sustainable wealth creation and local economic development within the wider context of sustainable development require new entrepreneurial initiatives that focus on investing in the local environment. . . . employing people and their resources" (2004: p. 441).

Green growth, therefore, requires a transformation that is influenced by one's strong motivation to create new products. By doing this the socially responsible investment can be ensured as a strategy. Adopting this strategy generates competitive advantages for both investors and beneficiaries (Tandoh-Offin 2010; Young, 2010). The people having potential for engaging in ecological entrepreneurial practices would be recognized for their expertise in practicing sustainable approaches to survival, which are derived from their perceptions, attitudes, and ecological identity. Further it is noted that the ecological entrepreneurship is directly related to the climate changes occurring, as these are inducing alterations to the global atmosphere. These alterations are directly or indirectly results of human activities (Momodu, Akinbami, and Obisanya, 2011).

In this relation, enhancing awareness among masses and developing skills are necessary to persuade initiators to get on board the green economy platform. The primary task is to influence perceptions and attitudes and to motivate good investment behaviors. This idea comes from the recognition that social constructs (collectivism and altruism) that play a vital role in facilitating start-up intentions with regard to pro-environmental ventures. Cultural factors are determinants in developing intentions regarding adoption of ecological entrepreneurship (Koe and Majid, 2014). This is the reason, the current study considered collectivism and altruism as the moderators in defining adoption of eco-preneurship as means of sustainability. By presenting a model of cultures' association with entrepreneurship, Hayton George, Zahra (2002) provided a broad overview of the potential pattern of relationships between national culture, contextual factors, and entrepreneurial outcomes. Culture is depicted as a moderator in the relationship between contextual factors (institutional and economic) and entrepreneurial outcomes. This suggests that culture acts as a catalyst rather than a causal agent of entrepreneurial outcomes, thus this calls for examining the role of cultural characteristics like such as collectivism and altruism. Ecology and sustainability entrepreneurship research has emerged from the huge body of business, environment and corporate responsibility literature while trying to find the answers to the questions like how the change in the business practices effect the business, social and environmental practices. The sustainable entrepreneurship research area has overlapped the organizational studies and the sustainable development literature, giving rise to another insight, sustainability enterprise as another field of study. Collectivism as derived from the theory of social learning and altruism based on social/national identity seems to be important factors that can have impact on the intentions of individuals to adopt ecofriendly/ sustainable practices.

\section{Ecopreneurship Intentions and Theory of Planned Behavior}

Krueger et al. (2000), starting a new business cannot be accidental rather it requires long term planning and positive intentions toward the new business so it is more of a planned behavior. Theory of planned behavior (TPB), extension of theory of reasoned action (TRA) (Ajzen, 1991; Ajzen and Fishbein, 1970) has been widely used by many researchers not only in social psychology (Armitage and Conner, 2001; Collins and Carey, 2007; Fielding et al., 2008) but also in for predicting behavioral intentions generally and environmental conscious behavioral intentions particularly. For the study of pro environmental behavior, many researchers have used TPB theoretical foundations (e.g., Bamberg and Schmidt, 2001; Bamberg et al., 2003; Chen and Tung, 2010; Kim and Han, 2010 and Han and Kim, 2010). Some of these studies combined or extended the TPB proposed model. 


\section{The International Journal}

ENTREPRENEURSHIP AND SUSTAINABILITY ISSUES

ISSN 2345-0282 (online) http://jssidoi.org/jesi/

2018 Volume 6 Number 2 (December)

http://doi.org/10.9770/jesi.2018.6.2(4)

Despite the general usefulness of the TPB, several studies made efforts to improve the explanatory power of this theory by adding additional constructs within the TPB model (Botetzagias, Dima, and Malesios, 2015; Kaiser and Scheuthle, 2003).

Intentions are considered to be an important factor in explaining actual behaviors. Strong intention to perform a certain behavior is most likely to result in its performance (Ajzen, 1991). TPB, successfully explains that how the positive behavioral intentions result in the actual behavior. The model of theory of planned behavior has been repeatedly used by many researchers in explaining the green behavioral intentions (Kalafatis, Pollard, East and Tsogas, 1999; Han, Hsu, and Sheu, 2010; Ryu and Han, 2010). The definition and measurement of behavioral intentions varies across existing literature however, the researchers are broadly agreed that it is readiness or likelihood to conduct a specific behavior (e.g. Ajzen, 1991, 2009; Han and Ryu, 2007; Oliver, 1997). The theoretical advantages of TPB-based work in entrepreneurship area cannot be denied. Linan, Nabi and Krueger (2013) very rightly have identified the four major focused areas of TBP by entrepreneurship researchers, the first one where the researchers have focused on studying the impact of core elements of TPB on entrepreneurial intention, the second stream has tried to study the impact of human and social capital on TPB elements and entrepreneurial intention, the third stream focused on the study of the effect of knowledge and awareness on TPB model and last but not the least, cross cultural comparisons on TPB model with reference to entrepreneurial intentions.

TPB model has been repeatedly used by many entrepreneurship researchers for identification of entrepreneurship intentions however, its power to explain the intention towards sustainable entrepreneurship has not been fully explored (Koe and Majid, 2014). Attitudes are considered to be an important driver of new venture intentions and many researchers (e.g. Moriano et al., 2012; do Paço et al., 2011 etc) in this area have found significant positive impact of attitudes on entrepreneurial intentions. Similarly, attitudes are also found to be predictor of pro environmental behavioral intentions in individuals (Stern, 2006; Bamberg and Möser, 2007). Sustainable practice adoption is also affected by positive or negative attitude of individuals (Chen et al., 2011). Subjective norms (pressures from influential others) have also been identified as predictor of sustainable behavioral intentions (Vermeir and Verbeke, 2008). Similarly, Meek (2010) and Yaacb (2010) found that environmental actions of entrepreneurs are resultant of social pressures. The behaviorists and psychologists are agreed upon the various concepts having impact on the processing capabilities for task accomplishments or solving problems and found a linkage between self-efficacy and motivation to behaviorail change (Drnovšek, Wincent and Melissa, 2010; Tzchentke, Kirk, and Lynch, 2008; Luszczynska, Gutierrez-Dona and Schwarzer, 2005; Pearlmutter, 1998; Tilley, 1999). Researchers have linked self-efficacy with various constructs like achievements, emotional disorders, mental and physical health, selecting careers etc. (McCormick, Tanguma and López-Forment, 2002). It is to highlight that the concept of self-efficacy is also relevant to the conservation of resources and adoption of proenvironmental behavior, where the research is found scarce (Dumitru, Budică, and Budică, 2017; Janmaimool, 2017; Drnovšek, Wincent and Melissa, 2010; Homburg and Stolberg, 2006). Individuals cannot contribute positively towards protecting the environment unless they have confidence for better environmental management. Hence based on above literature support following hypotheses are proposed:

$\mathrm{H}_{1}$ : Attitude toward ecopreneurship has a positive effect on ecopreneurship intentions.

$\mathrm{H}_{2}$ : Subjective norms has a positive effect on ecopreneurship intentions.

$\mathrm{H}_{3}$ : Self-efficacy has a positive effect on ecopreneurship intentions.

\subsection{Ecopreneurship Intentions and Collectivism}

People with individualistic orientations are independent, self-reliant, exercise freedom of choice and feel high level of competition from people around them (Triandis, 1995; Kim and Choi, 2005), whereas with collectivist orientation people are more interdependent, try to maintain in-group harmony, give importance to social 


\section{The International Journal}

ENTREPRENEURSHIP AND SUSTAINABILITY ISSUES

ISSN 2345-0282 (online) http://jssidoi.org/jesi/ 2018 Volume 6 Number 2 (December) http://doi.org/10.9770/jesi.2018.6.2(4)

hierarchies, have cooperative behavior and feel less competition (Hosfstede, 1980; Triandis, 1995). This value orientation has been investigated at both aggregate levels for the identification of differences across cultures and at individual levels for the identification of difference in the value orientation of individuals within a culture (Leonidou, Skarmeas, and Saridakis, 2018; Tascioglu, Eastman, and Iyer, 2017; Kim and Choi, 2005). This value orientation has been found to influence a range to social behaviors of individuals. Individual level of individualistic or collectivistic orientation has an impact on the motivation of individuals to perform certain behavior (Kim and Choi, 2005). Collectivistic tendencies of individuals have a positive impact on their pro environmental attitudes whereas people with individualist orientation view pro environmental behavior as less important and hence are less likely to engage in environmental friendly activities (McCarty and Shrum, 2001). Laroche et al. (2001) suggest that collectivist people tend to be friendlier toward the environment. Ling-Yee (1997) found similar results for ecological commitment and Kim and Choi (2005) for green purchase behavior. But little is known about the potential influences of collectivism or individualism on attitudes and intentions for ecological entrepreneurship. Values have been theoretically reasoned and empirically proven to have an important role in predicting specific attitudes and behaviors (De Groot and Steg, 2008; Stern and Dietz, 1994). Intentions of individuals are directly affected by their value orientations. Individuals try to stick with the value congruent information and disregard the information that is incongruent with their value orientation (Stern et al., 1995; Verplanken and Holland, 2002). A person with individualistic orientation would be more concern about him and pay less importance to the environment. Hence the following hypotheses are proposed

$\mathrm{H}_{4 \mathrm{a}}$ : Collectivism will moderate the relationship of attitude and ecopreneurship intentions.

$\mathrm{H}_{4 \mathrm{~b}}$ : Collectivism will moderate the relationship of subjective norms and ecopreneurship intentions.

$\mathrm{H}_{4 \mathrm{c}}$ : Collectivism will moderate the relationship of self-efficacy and ecopreneurship intentions.

\subsection{Ecopreneurship intentions and Altruism}

Moral norm-activation theory by Schwartz (1977) suggests that behavior become more probable when one is aware of its consequences. According to this theory, altruistic behaviors occur due to personal moral norms of individuals that are triggered as a result of an awareness about the negative consequences (condition pose threats to others) of certain behavior and the believe that their actions can reduce these negative consequences. As the environmental conscious behavior involves a tradeoff between individual and collective benefit many authors (e.g. Black, 1978; Black et al., 1985; Guagnano, Stern and Dietz, 1995; Schultz and Zelezny, 1999; Guagnano, 2001) have conceptualized it within the framework of Schwartz (1977) model of altruism and have provided substantial support of this theory while applying it to range to environmental issues. Guagnano (2001) after empirical analysis identified that in contrast to self-interest, market and market like behaviors are motivated by altruism. While studying the willingness to pay extra for recycled products, Guagnano (2001) validates the applicability of Schwartz (1977) model of moral norm activation. A person with high altruism would pay attention to the negative consequences of environmental problems and its impacts on humans and biosphere and would have pro environmental attitudes. Hence, it is proposed that the altruism has an impact on attitudes, behavior and intentions of individuals.

$\mathrm{H}_{5 \mathrm{a}}$ : Altruism will moderate the relationship of attitude and eco-preneurship intentions.

$\mathrm{H}_{5 \mathrm{~b}}$ : Altruism will moderate the relationship of subjective norms and eco-preneurship intentions.

$\mathrm{H}_{5 \mathrm{c}}$ : Altruism will moderate the relationship of self-efficacy and eco-preneurship intentions.

\subsection{Dual Moderating Role of Collectivism and Altruism}

The values (collectivism) and norms (Altruism) play a very important role in developing pro-environmental behavior (Guagnano, 2001; Kim and Choi, 2005) in individuals. Moral norm-activation theory by Schwartz (1977) and Kim and Choi (2005) identification of value orientation impact on pro environmental behaviors in individuals provide indication for the additive moderating role of collectivism and altruism. Although, 
collectivism and altruism are two different type of values/norms. There is a possibility that an individual may possess either collectivism or altruism, or both. Hence, it is proposed that collectivism and altruism both may play additive moderating role (three-way interaction) in the relationships of TPB. Based on the above discussion following hypotheses are proposed:

$\mathrm{H}_{6 \mathrm{a}}$ : Collectivism and altruism will play additive moderating role in the relationship of attitude and ecopreneurship intentions.

$\mathrm{H}_{6 \mathrm{~b}}$ : Collectivism and altruism will play additive moderating role in the relationship of subjective norms and ecopreneurship intentions.

$\mathrm{H}_{6 c}$ : Collectivism and altruism will play additive moderating role in the relationship of self-efficacy and ecopreneurship intentions.

Based on above discussion, extended theory of planned behavior model for identification of drivers of ecopreneursip intentions is proposed (Figure 1).

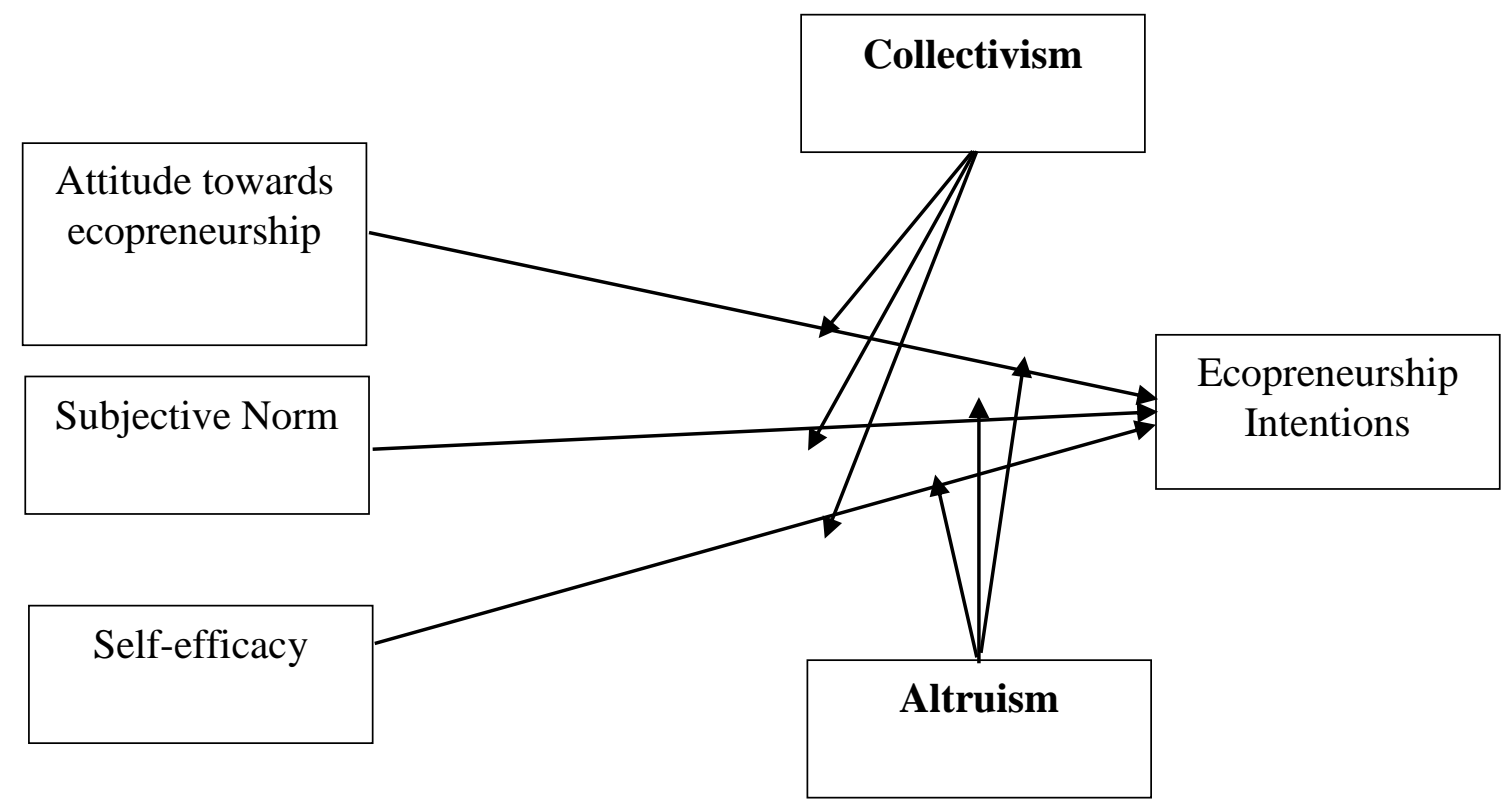

Figure 1. Drivers of ecopreneursip intentions

\section{Methodology}

\subsection{Data collection}

Data were collected from entrepreneurship and innovation students from one public and one private sector universities from a rural district of Pakistan and participants of a training workshop held in Fatima Jinnah Women University, Rawalpindi, Pakistan in July 2017 the title of workshop was "Creating and Strengthening the Awareness of Financial Linkages among the Young Women Entrepreneurs in the Rural Areas of Rawalpindi District" under Social Integration Outreach Program, of Higher Education Commission, Islamabad. The students were enrolled in the undergraduate program of business administration departments of the two universities and participants of training workshop were females who were interested in starting a new business in near future. Non-probability purposive sampling technique was used where the respondents were selected based on their enrollment in entrepreneurship and innovation course and the participants of the training workshop. 
Questionnaires (Saunders, Lewis, and Thornhill, 2012) were distributed either using online google docs or in hard form for the workshop participants. Serial mean was used for imputation of missing values and after imputation of missing values total usable sample size was 292 (Missing value imputations were used for confirmatory factor analysis). Majority of the respondents were males (189 males; 70 females), belonging to the age group of 24-27 years. The mean family income was $\$ 500-\$ 1000$.

\subsection{Measures}

Entrepreneurial Intention Questionnaire: Entrepreneurial Intention Questionnaire (EIQ) developed by Liñán, Battistelli, and Moriano, (2008) was adopted for the assessment of the ecological entrepreneurial dispositions of respondents. Attitude toward eco-preneurship was measured with the help of five items measured on 5-point likert scale where 1 was "strongly disagree" to 5 as "Strongly Agree". Sample item is "A career as an ecological entrepreneur is totally unattractive to me" a subjective norm for eco-preneurship was measured using three items and self-efficacy for eco-preneurship was measured with the help of six itemed scale. Similarly, Intentions toward eco-preneurship was measured with the help of four questions sample items are "I am ready to do anything to be an ecological entrepreneur" and "I will make every effort to start and run my own environmentally friendly business".

Collectivism: Collectivism was measured on a seven-point, three-item scale measured on (1) "not at all important" to (7) "extremely important" adopted from Yamaguchi (1990). The sample items are 1) "I maintain harmony in my group. 2) I respect the majority's wish and 3) I sacrifice self-interest for my group. None of the item was reverse coded."

Altruism: For the measurement of altruism, we used a 7-item scale developed by Guagnano (2001). Items were measured on 7-point Likert scale $(1=$ strongly disagree; $7=$ strongly agree). The sample items are 1$)$ "Over the next several decades, thousands of species on earth will be driven to extinction 2) The effects of environmental problems on public health are worse than we realize 3) Current claims that environmental problems are changing the earth's climate are exaggerated, and 4) Protecting the environment will threaten jobs for people like me". Item 3,4 and 5 were reverse coded.

\subsection{Data Analysis}

Data were analyzed using SPSS, AMOS and PROCESS Procedure for SPSS Release 2.16.3 written by Andrew F. Hayes, Ph.D. the process was downloaded from www.afhayes.com.

\subsubsection{Common Method Variance}

Self-reported data raise issue of potential effect of common method variance (CMV) (Podsakoff et al., 2003). Prior to hypothesis testing, CMV was tested using Harman's one factor test. When all items were loaded in principal component factor analysis 5 factors with "eigen value" greater than 1 were formed and the first factor accounted for less than $30 \%$ variance. The result revealed that data is free from CMV.

\subsubsection{Reliability}

Reliability of the collected data set was checked with the help of Corbatch's Alpha and composite reliabilities coefficient (Nunnally, 1978). The value of Cronbatch alpha coefficient for all variable understudy ranged between 0.697 and 0.936 and composite reliability coefficient values lie between 0.688 to 0.886 showing the acceptable reliability of the data (Hair et al., 2014). Results are present in Table 1. 
Table 1. Confirmatory Factor Analysis of Items Present in Model

\begin{tabular}{|c|c|c|c|c|c|c|}
\hline Construct/Variable & $\mathbf{B}$ & Alpha & CR & AVE & SK & KU \\
\hline Attitude & & .803 & 0.803 & 0.451 & 1.39 & 1.97 \\
\hline ATT1 & .640 & & & & & \\
\hline ATT2 & .640 & & & & & \\
\hline ATT3 & .718 & & & & & \\
\hline ATT4 & .673 & & & & & \\
\hline ATT5 & .683 & & & & & \\
\hline Subjective Norms & & .697 & 0.688 & 0.425 & 0.87 & -0.19 \\
\hline SN1 & .662 & & & & & \\
\hline $\mathrm{SN} 2$ & .611 & & & & & \\
\hline $\mathrm{SN} 3$ & .681 & & & & & \\
\hline Self-Efficacy & & .884 & 0.849 & 0.563 & 1.11 & 0.40 \\
\hline SE1 & .749 & & & & & \\
\hline SE2 & .786 & & & & & \\
\hline SE3 & .788 & & & & & \\
\hline SE4 & .768 & & & & & \\
\hline SE5 & .743 & & & & & \\
\hline SE6 & .662 & & & & & \\
\hline Intentions & & .926 & 0.928 & 0.763 & -1.14 & 0.68 \\
\hline INT1 & .805 & & & & & \\
\hline INT2 & .875 & & & & & \\
\hline INT3 & .925 & & & & & \\
\hline INT4 & .885 & & & & & \\
\hline Collectivism & & .881 & 0.815 & 0.596 & -0.49 & 0.17 \\
\hline COL1 & 670 & & & & & \\
\hline COL2 & .853 & & & & & \\
\hline COL3 & .783 & & & & & \\
\hline Altruism & & .936 & 0.886 & 0.651 & 0.01 & -0.65 \\
\hline ALT1 & .657 & & & & & \\
\hline ALT2 & .956 & & & & & \\
\hline ALT3 & .761 & & & & & \\
\hline ALT4 & .755 & & & & & \\
\hline ALT5 & .902 & & & & & \\
\hline ALT6 & .774 & & & & & \\
\hline
\end{tabular}

\subsubsection{Normality}

Normality of data was ensured with the help of skewness and kurtosis values (Winer, Brown and Michels, 1991). For all constructs, the values of skewness and kurtosis values lie between +1 and -1 Hence, indicating that data were normally distributed. Results are presented in Table 1.

\subsubsection{Validity}

Convergent and discriminant validity indices were used to ensure the validity of data set. For convergent validity, the regression coefficients for each observed variable (Item) should be greater than 0.6 (Joreskog and Sorbom, 2006), all items were loaded in to their respective latent construct with regression coefficient greater than 0.6, results are presented in Table 1. Similarly, discriminant validity was confirmed using Fornell and Larker (1981) criteria where the AVE for each variable should be greater than the shared variance for all constructs present in the proposed model (Fan et al., 2006). For all constructs, the AVE were greater than shared variance except for self-efficacy where shared variance was greater than AVE of two constructs. Results are present in Table 2. 
Table 2. Descriptive Statistics, Correlations and Shared Variance for Constructs

\begin{tabular}{|c|c|c|c|c|c|c|c|c|c|c|}
\hline Items & Variable & No of items & Mean & S. D & $\mathbf{1}$ & 2 & 3 & 4 & 5 & 6 \\
\hline 1 & Attitude & 5 & 1.69 & 0.721 & .45 & & & & & \\
\hline 2 & Subjective Norms & 3 & 1.68 & 0.719 & $\begin{array}{l}.67 * \\
(.44)\end{array}$ & .43 & & & & \\
\hline 3 & Self-Efficacy & 6 & 1.60 & 0.377 & $\begin{array}{l}.66^{*} \\
(.43)\end{array}$ & $\begin{array}{l}.78^{*} \\
(.60)\end{array}$ & .56 & & & \\
\hline 4 & Intentions & 4 & 3.99 & 1.094 & $\begin{array}{l}.20^{*} \\
(.04)\end{array}$ & $\begin{array}{l}.30^{*} \\
(.90)\end{array}$ & $\begin{array}{l}.32^{*} \\
(.10)\end{array}$ & .76 & & \\
\hline 5 & Collectivism & 3 & 4.83 & 1.455 & $\begin{array}{c}-.05 \\
(0.002)\end{array}$ & $\begin{array}{l}.20 * \\
(.04)\end{array}$ & $\begin{array}{l}.15^{*} \\
(0.02)\end{array}$ & $\begin{array}{c}.33 * \\
(0.12)\end{array}$ & .60 & \\
\hline 6 & Altruism & 6 & 3.95 & 1.522 & $\begin{array}{c}.04 \\
(0.002)\end{array}$ & $\begin{array}{c}.08 \\
(0.006)\end{array}$ & $\begin{array}{c}.08 \\
(0.006)\end{array}$ & $\begin{array}{c}-.07 \\
(0.005)\end{array}$ & $\begin{array}{c}.13^{* *} \\
(0.017)\end{array}$ & .65 \\
\hline
\end{tabular}

Note: Shared variance in parenthesis; AVE in diagonal; * $\mathrm{P}<0.01$;

\subsubsection{Confirmatory Factor Analysis}

Three different CFA models (Kaplan, 2000) were constructed including two factor model having attitude, subjective norms, self-efficacy, collectivism and altruism as single construct and intentions as a separate construct, three factor model having attitude, subjective norms and self-efficacy as one construct and collectivism and altruism as second construct and intentions as the third construct and finally the six-factor model where all constructs were loaded as separate constructs. Results identify that the proposed six-factor model is the best fitted model compare to two or three factor models. Results are presented in Table 3.

Table 3. Summary of CFA Results

\begin{tabular}{|c|c|c|c|c|c|c|}
\hline Model & $\chi^{2}(\mathrm{df}), \mathrm{df} / \chi^{2}$ & CFI & RMR & GFI & RMSEA & $\begin{array}{c}\text { Comparison with } \\
6 \text { factor models } \\
\left(\Delta \chi^{2}, \mathrm{df}\right) \\
\end{array}$ \\
\hline Model 1 (2 factors) & $1526,(316), 4.8$ & 0.798 & 0.359 & 0.776 & 0.115 & $877,(14)$ \\
\hline Model 2 (3 factors) & $1085,(314), 3.4$ & 0.872 & 0.157 & 0.856 & 0.092 & $436,(12)$ \\
\hline Model 3 (6 factors) & $649,(302), 2.1$ & 0.942 & 0.069 & 0.933 & 0.063 & \\
\hline
\end{tabular}

Finally, CFA was performed by taking all constructs (latent and observed) including dependent, moderators and independent at a time. The results of the measurement model identified that all observed variables had t-values greater than 2.50, their factor loadings were greater than 0.5 and R2 was also greater than 0.5 . However, three items were deleted from analysis due to cross loading (one item from altruism and two items from intentions) (Joreskog and Sorbom, 2006).

\subsection{Regression Analysis}

Multiple linear regression analysis was used to test the impact of attitude, subjective norms and self-efficacy on ecological entrepreneurship intentions. The results are presented in Figure 2. Subjective norms and self-efficacy have significant positive impact on ecological entrepreneurship intentions while attitude toward ecological entrepreneurship remain insignificant. 


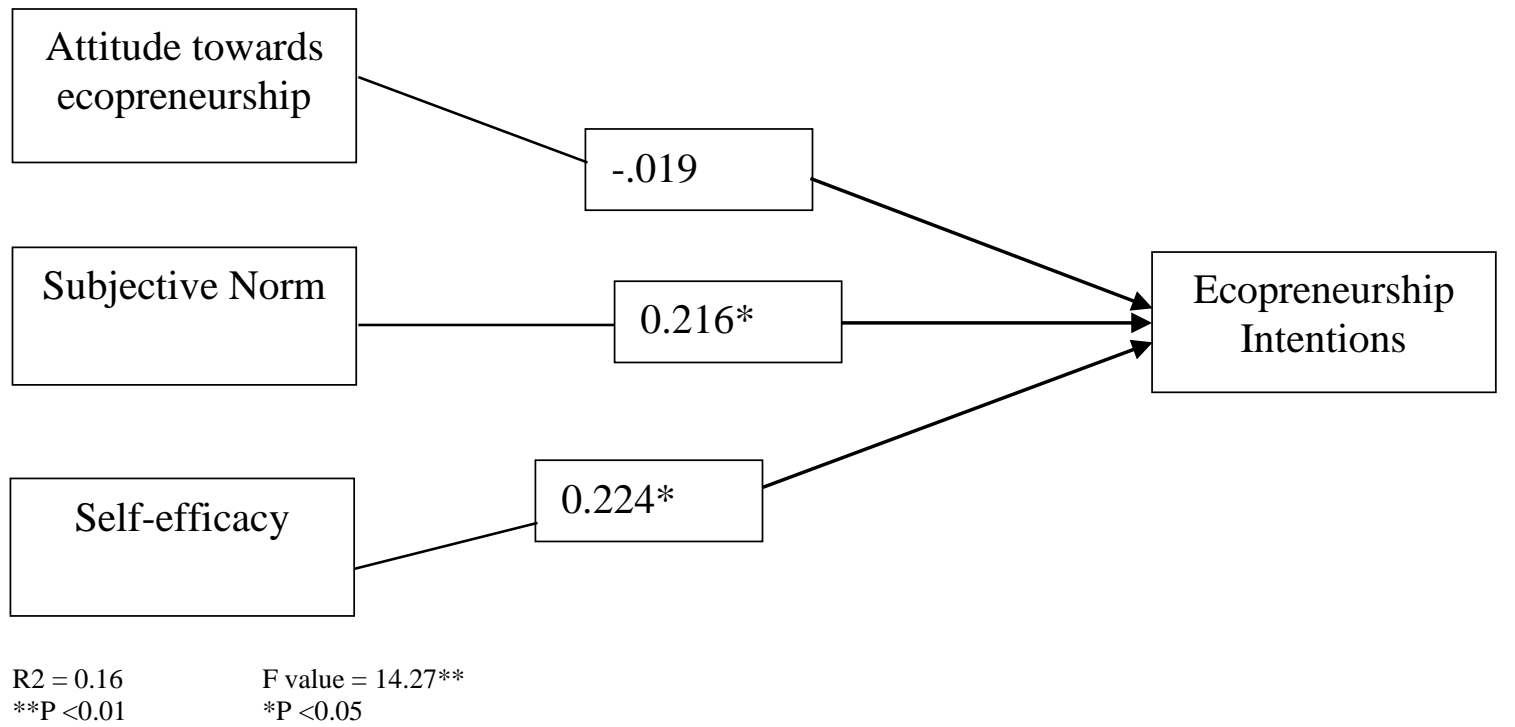

Figure 2. OLS Regression Results

\subsection{Moderation Analysis}

For testing of the moderating impact of collectivism and altruism on the proposed relationships PROCESS macro developed by Hayes (2013) for SPSS was used. We use PROCESS macro particularly due to the fact that PROCESS allows integrating multiple moderating variables in a single model. The study intended to estimate whether attitude, subjective norms, self-efficacy (X1, X2, X3) and ecopreneuship intentions (Y) is moderated by collectivism (MV1) and altruism (MV2) simultaneously. We used Model 2, which allows testing of the two moderators with bootstrap confidence intervals. The results of moderation analysis are presented in the following tables. (Hayes, 2013). To do so, the study run the process model by mean centering attitude, subjective norms, self-efficacy, collectivism (MV1) and altruism (MV2) using process model inbuilt option. The process output illustrated in first part the overall model fitness by estimating the direct impact of the variables of the study namely attitude, subjective norms, self-efficacy (X1, X2, X3) and the interactions terms i.e. int_1 of MV1 and int_2 of MV2 on the dependent variable, ecopreneuship intentions (Y). The output then illustrated the effect of interaction terms separately and collectively through the magnitude of R2-change. Results of PROCESS macro for SPSS are presented in Table 4 and Table 5.

Table 4. Moderation Analysis (PROCESS Model 2)

Bootstrap (5000 re-sample) Results

\begin{tabular}{llllll}
\hline Predictors & Beta & Std. Error & t-value & LLCI & ULCI \\
\hline Attitude & $0.468^{*}$ & 0.10 & 4.80 & .6591 & .2760 \\
Collectivism & $0.279^{*}$ & 0.05 & 5.84 & .1850 & .3730 \\
Altruism & 0.040 & 0.04 & 1.06 & -.0377 & .1257 \\
Attitude X Collectivism & $0.167^{* * *}$ & 0.09 & 1.82 & .0140 & .3489 \\
Attitude X Altruism & $0.150^{* *}$ & 0.08 & 1.98 & .0006 & .2985 \\
R2 & .20 & & & & \\
F-value & $13.7^{*}$ & & & &
\end{tabular}


The International Journal

ENTREPRENEURSHIP AND SUSTAINABILITY ISSUES

ISSN 2345-0282 (online) http://jssidoi.org/jesi/

2018 Volume 6 Number 2 (December)

http://doi.org/10.9770/jesi.2018.6.2(4)

\begin{tabular}{llllll}
\hline Subjective Norms & $0.485^{*}$ & 0.09 & 5.69 & .6518 & .3170 \\
Collectivism & $0.223^{*}$ & 0.05 & 4.70 & .1314 & .3209 \\
Altruism & 0.060 & 0.04 & 1.47 & -.0203 & .1408 \\
Subjective Norms X Collectivism & $0.132^{*}$ & 0.06 & 2.02 & .0032 & .2603 \\
Subjective Norms X Altruism & 0.091 & 0.06 & 1.53 & -.0259 & .2071 \\
R2 & .22 & & & & \\
F-value & $16.1^{*}$ & & & & \\
& & & & & \\
Self-Efficacy & $0.528^{*}$ & 0.08 & 6.44 & .6890 & .3664 \\
Collectivism & $0.240^{*}$ & 0.05 & 5.09 & .1470 & .3325 \\
Altruism & 0.059 & 0.04 & 1.45 & -.0210 & .1385 \\
Self-Efficacy X Collectivism & 0.085 & 0.07 & 1.23 & -.0512 & .2215 \\
Self-Efficacy X Altruism & $0.111^{* * *}$ & 0.06 & 1.89 & .0044 & .2262 \\
R2 & .24 & & & & \\
F-value & $17.9^{*}$ & & & & \\
\hline Note: $*$ P $<0.01, * * \mathrm{P}<0.05,{ }^{* * *} \mathrm{P}<0.10$ & & & & &
\end{tabular}

Table 5. R-square increase due to interaction(s)

\begin{tabular}{lcl}
\hline \multicolumn{1}{c}{ Interaction (s) } & $\boldsymbol{\Delta R}^{\mathbf{2}}$ & F-value \\
\hline Attitude X Collectivism & 0.009 & $3.30^{* * *}$ \\
Attitude X Altruism & 0.011 & $3.91^{*}$ \\
Attitude X Collectivism X Altruism & 0.026 & $4.64^{*}$ \\
Subjective Norms X Collectivism & 0.011 & $4.07^{*}$ \\
Subjective Norms X Altruism & 0.006 & 2.34 \\
Subjective Norms X Collectivism X Altruism & 0.022 & $3.99^{* *}$ \\
Self-Efficacy X Collectivism & 0.004 & 1.51 \\
Self-Efficacy X Altruism & 0.009 & $3.59^{* * *}$ \\
Self-Efficacy X Collectivism X Altruism & 0.019 & $3.47 * *$ \\
\hline Note: $* \mathrm{P}<0.01, * * \mathrm{P}<0.05, * * * \mathrm{P}<0.10$ & &
\end{tabular}

The both interactions of collectivism and altruism with attitude are significant, identifying the moderating impact of collectivism and altruism on the relationship of attitude and ecopreneurship intentions. Similarly, the three-way interaction (Attitude $\mathrm{X}$ Collectivism X Altruism) is also significant with $\Delta \mathrm{R}^{2}=3 \%$, identifying the combined role of collectivism and altruism on the relationship of attitude and ecopreneurship intentions. Hence, hypotheses H4a, $\mathrm{H} 5 \mathrm{a}$ and H6a are supported. This is also evident from three-way interaction plot. 


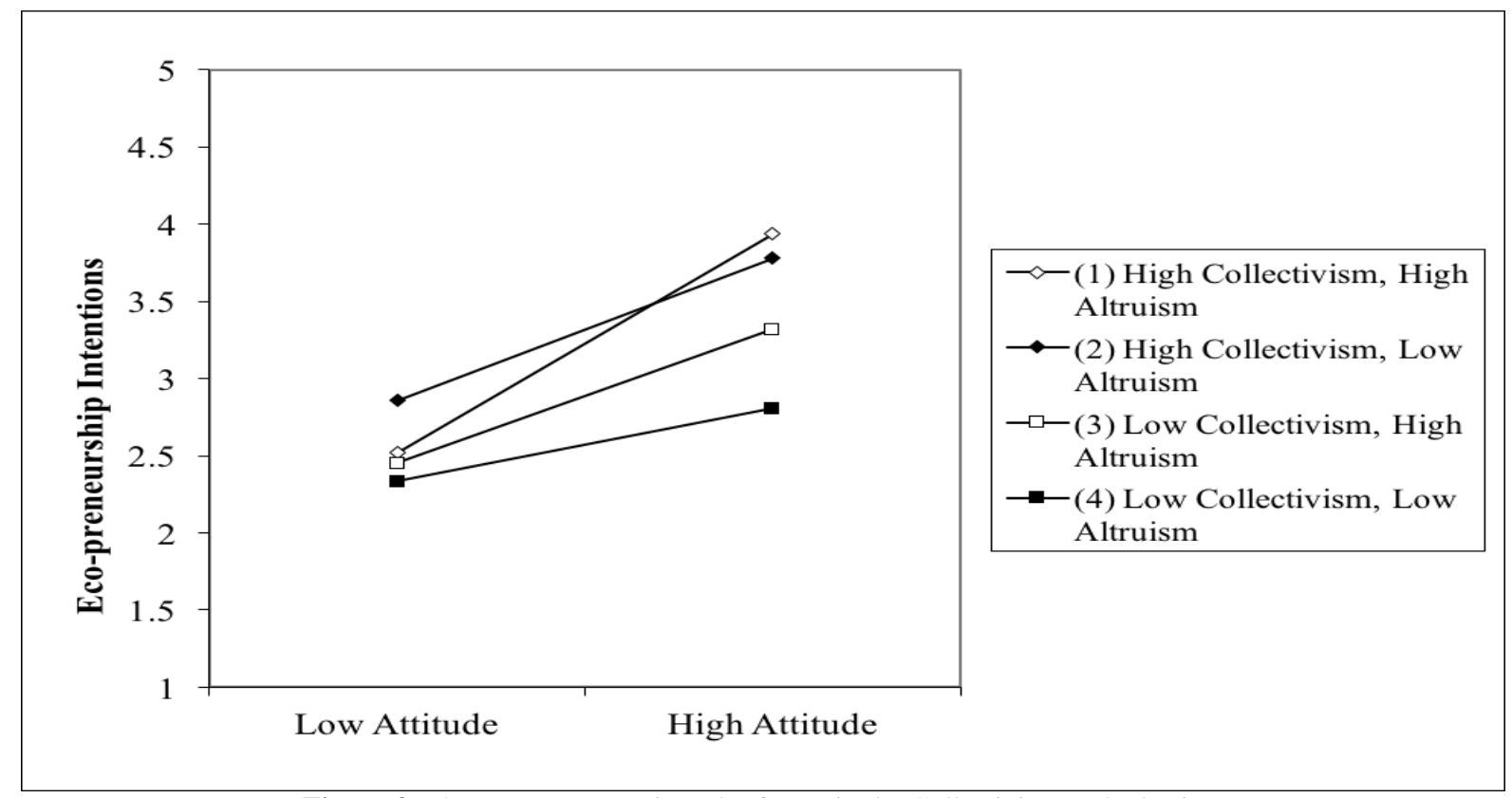

Figure 3. Three Way Interaction Plot for Attitude, Collectivism and Altruism

In case of subjective norms, the moderating role of collectivism is significant and altruism is insignificant. However, the three-way interaction (Subjective Norms X Collectivism X Altruism) is significant with $\Delta \mathrm{R}^{2}=2 \%$. This identifies the importance of the existence of combined effect of collectivism and altruism on the relationship of subjective norms and ecopreneurship intentions. Hence, hypotheses $\mathrm{H} 4 \mathrm{~b}$ and H6b are supported. This is also evident from three-way interaction plot.

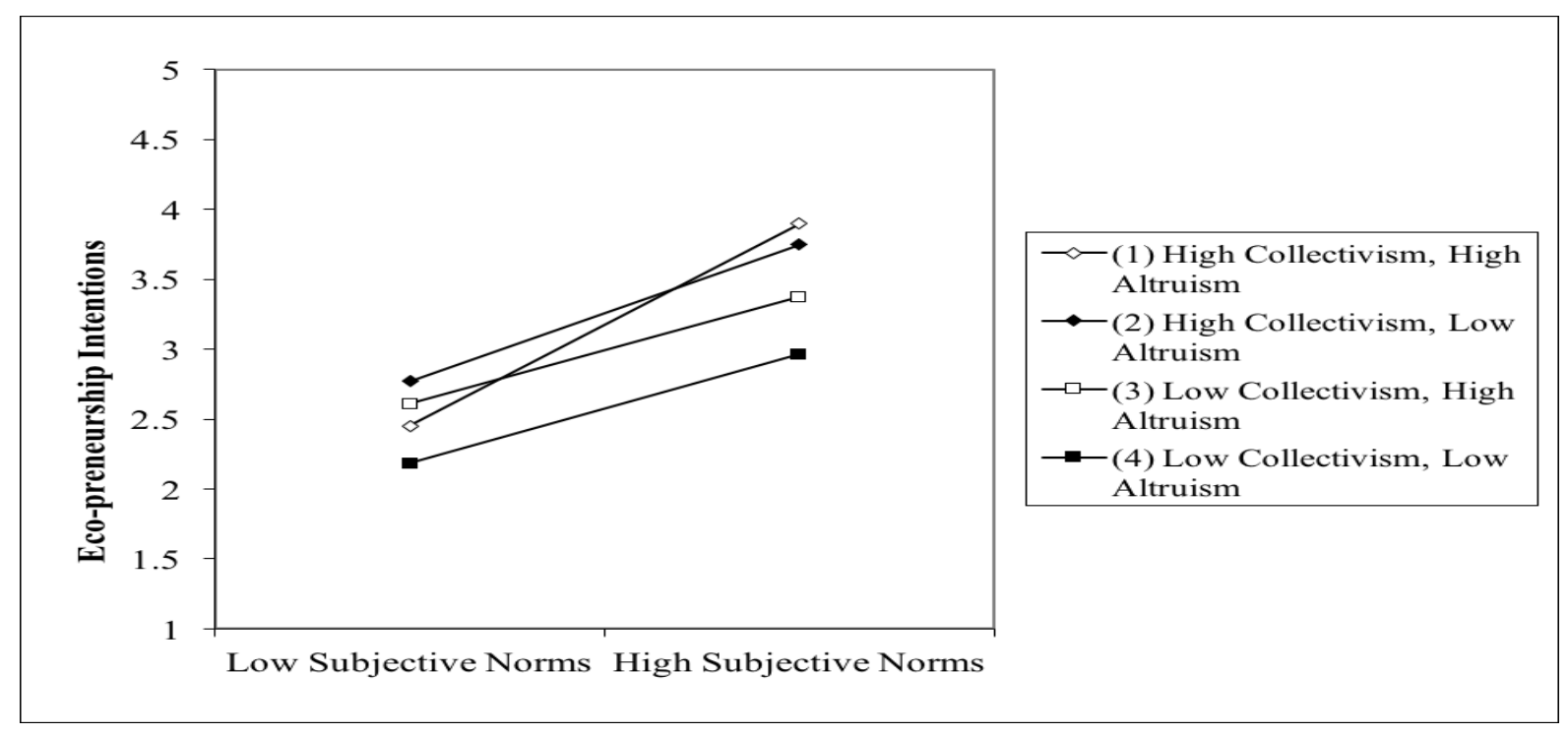


Figure 4. Three Way Interaction Plot for Subjective Norms, Collectivism and Altruism

For self-efficacy, altruism interaction and three-way interaction (Self Efficacy X Collectivism X Altruism) are significant. Hence, hypotheses H5c and H6c are supported. See figure 5 for three-way interaction plot.

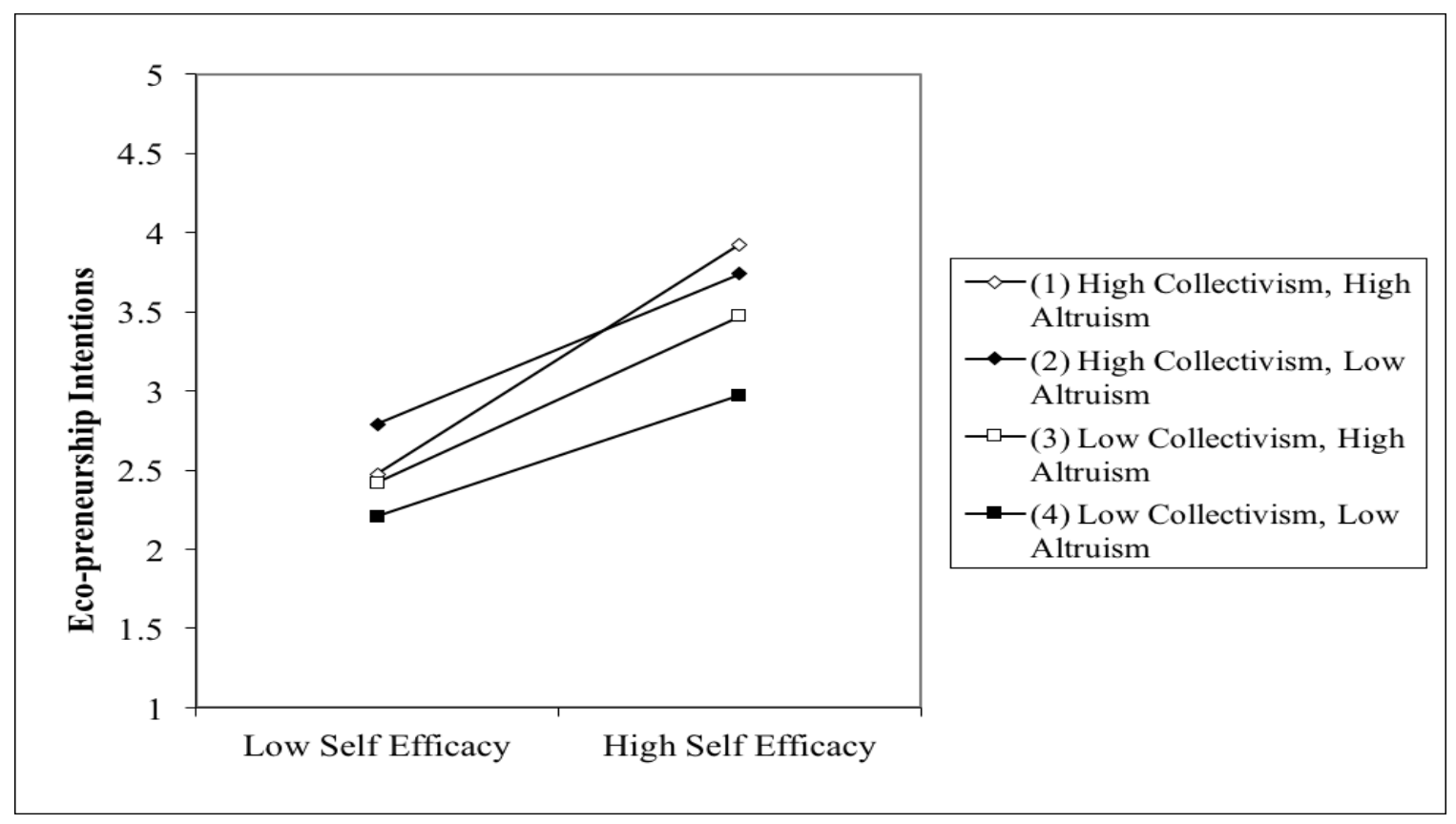

Figure 5. Three Way Interaction Plot for Self-efficacy, Collectivism and Altruism

\section{Discussion}

In this study, we have presented and tested an extended theory of planned behavior (Ajzen, 1991) model specifically for explaining the ecopreneurship intentions by incorporating the moderating role of altruism and collectivism. The most important finding of the current study is the insignificant relationship of attitudes with ecopreneurship intentions which become significant in presence of collectivism and altruism. This not only identifies the importance of both the moderators but also provides insight about the fact that the attitude toward ecopreneurship can become significant only if altruistic and collectivist behavior exists not otherwise. This finding substantiates Schwartz (1977) model of moral norm activation according to which people with high altruistic values would be able to show pro environmental behavior.

The second important finding revolves around subjective norms. Ecopreneurship intentions are significantly affected by subjective norms. It would be relevant for us at this stage to reflect on the context of the study. Societal culture does play a role in shaping behavior. The social and cultural environment of Pakistan is relationship oriented, with strong collectivist values (Hofstede, 1980). Since our sample was drawn from Pakistan the results might be explained with reference to the orientation of respondents. Collectivism is significant moderator while altruism remain insignificant moderators for subjective norms. However, the three-way interaction (Subjective Norms X Collectivism X Altruism) significantly produce $2 \%$ change. This identifies that presence of both moderators is required to enhance the relationship between subjective norms and ecopreneurship 
intentions. Attitudes and social norms were shown to have significant effects on the ecological entrepreneurship intentions in presence of moderators.

The third important finding is related to self-efficacy, having control over behavior. The relationship of selfefficacy and ecopreneurship intentions are also enhanced by altruism and its three-way interaction (Self Efficacy $X$ Collectivism $X$ Altruism). Self-efficacy is an important factor for encouraging the people to adopt ecopreneurship for the reason that there are chances of negative outcomes in the start of any business and the people with low self-efficacy may give up at earlier stages, thus hampering sustainable development of any business. The self-efficacy among students can be developed by providing relevant education and training, thus leading to positive outcomes (Wilson et al., 2007). While training the activity, practice and feedback prove to be important for developing performance standards, a sense of efficacy and expectations form performance (Bullough, Renko and Myatt, 2014). Further self-efficacy helps control negative thoughts by providing the confidence and fostering positive thoughts during achievement of the goals (Drnovšek, Wincent and Cardon, 2010).

Self-efficacy is an important component in minimizing the risk to the environment. Janmaimool (2017) viewed that when people have higher perceived severity, susceptibility as well as high perceived self-efficacy, they are likely to be involved in pro-environmental behaviors in order to minimize the risks. People learn/acquire skills for doing any activity (business) based on the self-efficacy (Bandura, 1997). Self-efficacy as a self-referent and cognitive mechanism can significantly influence the willingness of people to get involved in a certain activity and this further helps them to remove the barriers coming across the steps followed for achieving goals. People believing in the possession of skills and capability to handle environmental problems is important especially when the people feel pressures of increased demands towards them, when they are about to get involved with a new task area (adoption of ecoprenurship).

Last but not the least, Schwartz (1977) model of moral norm activation is also validated in new social, cultural, developing country context. The results support the idea that a person with high altruism would pay attention to the negative consequences of environmental problems and its impacts on humans and biosphere and would have pro environmental attitudes and positive ecopreneurship intentions. Similarly, when individuals think they are part of a larger group and have collectivistic tendencies their attitudes and intentions toward ecopreneurship become positive. This result is consistent with the findings of McCarty and Shrum (2001) and Laroche et al. (2001) who suggest that collectivist people tend to be friendlier toward the environment.

The study has few limitations related to the investigation regarding eco-entrepreneurial behavior. The students are considered for the study that may be a limiting factor in terms of their exposure to the ecoenterprenurial behavior and its impact on sustainability of the economies. The sample size considered for the study is another limiting factor, the bigger sample size with diversification in the sample selection may contribute to generating interesting results. Addition of the variables to the tested model on either side of the model that is independent variables, dependent variables or the variables having indirect effects that are mediators or moderators may add to the strength of the model. The different contextual contributions for testing model may add to the value of the findings derived in this study. The contextual contributions may be achieved by adding the responses from the teaching faculty imparting ecological entrepreneurship education, collection of the responses from the marketers marketing the ecological products, the producers who are producing eco-friendly products may influence the intentions of the entrepreneurs to get into this business etc. Further the methodology used for the study is quantitative with closed ended structured questionnaires, the change in methodology such as use of triangulation may add to the worth of the study. 
The International Journal

ENTREPRENEURSHIP AND SUSTAINABILITY ISSUES

ISSN 2345-0282 (online) http://jssidoi.org/jesi/

2018 Volume 6 Number 2 (December)

http://doi.org/10.9770/jesi.2018.6.2(4)

\section{Conclusion}

There is need to understand the importance of sustainability of economies by the students especially undergoing business education and look for avenues that provide support to sustainability, in which ecoprenureship is one. The results of the study show that the intentions to adopt ecoprenurship are not only affected by attitudes, subjective norms and self-efficacy, as identified by theory of planned behavior (Ajzen and Fishbein, 1975) but are also affected by the presence of some specific values and norms in individuals like collectivism and altruism. Further the social capital in terms of people having positive attitudes towards adoption add to the positive outcomes. To conclude, this study makes an important contribution to the literature on drivers of ecopreneurship by extending the theory of planned behavior model (Ajzen and Fishbein, 1975) by incorporating moderating role of collectivism and altruism and testing it in a developing country context. The ecopreneurship is mainly driven by subjective norms and self-efficacy while attitude towards ecopreneurship become significant in presence of collectivism and altruism not otherwise. Similarly, the dual moderating role of collectivism and altruism has been identified by the significance of three-way interactions for attitude, subjective norms and self-efficacy with collectivism and altruism.

\section{References}

Ajzen, I. \& Fishbein, M., 1975. Belief, attitude, intention and behavior: An introduction to theory and research. Reading, MA; AddisonWesley, Boston, Massachusetts. https://trove.nla.gov.au/version/26117886

Ajzen, I. \& Fishbein, M., 1980. Understanding attitudes and predicting social behaviour. Englewood Cliffs, NJ: Prentice-Hall.

Ajzen, I. 2012. The theory of planned behaviour, In Lange, P.A.M., Kruglanski, A.W. and Higgins, E.T. (Eds), Handbook of Theories of Social Psychology, Vol. 1. London: Sage. https://doi.org/10.4135/9781446249215.n22

Ajzen, I., 1991. The theory of planned behavior. Organizational behavior and human decision processes, 50(2): 79-211.

Armitage, C.J. \& Conner, M., 2001. Efficacy of the theory of planned behaviour: A meta-analytic review. British journal of social psychology, 40(4): 471-499. https://doi.org/10.1348/014466601164939

Bamberg, S. \& Möser, G., 2007. Twenty years after Hines, Hungerford, and Tomera: A new meta-analysis of psycho-social determinants of pro-environmental behaviour. Journal of environmental psychology, 27(1): 14-25. https://doi.org/10.1016/j.jenvp.2006.12.002

Bamberg, S. \& Schmidt, P., 2001. Theory-Driven Subgroup-Specific Evaluation of an Intervention to Reduce Private Car Use. Journal of Applied Social Psychology, 31(6): 1300-1329. https://doi.org/10.1111/j.1559-1816.2001.tb02675.x

Bamberg, S., Ajzen, I. \& Schmidt, P., 2003. Choice of travel mode in the theory of planned behavior: The roles of past behavior, habit, and reasoned action. Basic and applied social psychology, 25(3): 175-187. https://doi.org/10.1207/S15324834BASP2503_01

Black, J.S., Stern, P.C. \& Elworth, J.T., 1985. Personal and contextual influences on household energy adaptations. Journal of applied psychology, 70(1): 3-21. http://dx.doi.org/10.1037/0021-9010.70.1.3

Botetzagias, I., Dima, A. F., \& Malesios, C. (2015). Extending the theory of planned behavior in the context of recycling: The role of moral norms and of demographic predictors. Resources, conservation and recycling, 95, 58-67. https://doi.org/10.1016/j.resconrec.2014.12.004 


\section{ENTREPRENEURSHIP AND SUSTAINA International Journal \\ The International Journal}

ENTREPRENEURSHIP AND SUSTAINABILITY ISSUES

ISSN 2345-0282 (online) http://jssidoi.org/jesi/

2018 Volume 6 Number 2 (December)

http://doi.org/10.9770/jesi.2018.6.2(4)

Bullough, A., Renko, M. \& Myatt, T., 2014. Danger zone entrepreneurs: The importance of resilience and self-efficacy for entrepreneurial intentions. Entrepreneurship Theory and Practice, 38(3): 473-499. https://doi.org/10.1111/etap.12006

Canever, M. D., Barral, M. R. M., \& Ribeiro, F. G. (2017). How does the public and private university environment affect students' entrepreneurial intention? Education+ Training, 59(6), 550-564. https://doi.org/10.1108/ET-12-2016-0187

Chen, A.J., Watson, R.T., Boudreau, M.C. \& Karahanna, E., 2011. An institutional perspective on the adoption of Green IS and IT. Australasian Journal of Information Systems, 17(1). http://dx.doi.org/10.3127/ajis.v17i1.572

Chen, C.L. \& Jaw, Y.L., 2009. Building global dynamic capabilities through innovation: A case study of Taiwan's cultural organizations. Journal of engineering and technology management, 26(4): 247-263.

Chen, M.F. \& Tung, P.J., 2010. The moderating effect of perceived lack of facilities on consumers 'recycling intentions. Environment and Behavior, 42(6): 824-844. https://doi.org/10.1177/0013916509352833

Collins, S.E. \& Carey, K.B., 2007. The theory of planned behavior as a model of heavy episodic drinking among college students. Psychology of Addictive Behaviors, 21(4): 498. https://doi.org/10.1037/0893-164X.21.4.498

De Groot, J.I. \& Steg, L., 2009. Mean or green: which values can promote stable pro-environmental behavior? Conservation Letters, 2(2): 61-66. https://doi.org/10.1111/j.1755-263X.2009.00048.x

Do Paco, A., Ferreira, J., Raposo, M., Rodrigues, R.G. \& Dinis, A., 2011. Entrepreneurial intention among secondary students: findings from Portugal. International Journal of Entrepreneurship and Small Business, 13(1): 92-106. https://doi.org/10.1504/IJESB.2011.040418

Drnovšek, M., Wincent, J. \& Cardon, M.S., 2010. Entrepreneurial self-efficacy and business start-up: developing a multi-dimensional definition. International journal of entrepreneurial behavior and research, 16(4): 329-348. https://doi.org/10.1108/13552551011054516

Dumitru, A., Budică, A. B., \& Budică, A. F. (2017). The characteristics of the information contained in the synthesis reports. Social Sciences and Education Research Review, 4(1), 125-135. http://sserr.ro/wp-content/uploads/2017/08/4-1-125-135.pdf

Fan, Y., Chen, J., Shirkey, G., John, R., Wu, S.R., Park, H. and Shao, C., 2016. Applications of structural equation modeling (SEM) in ecological studies: an updated review. Ecological Processes, 5(1): 19-27. https://doi.org/10.1186/s13717-016-0063-3

Fielding, K.S., McDonald, R. \& Louis, W.R., 2008. Theory of planned behaviour, identity and intentions to engage in environmental activism. Journal of environmental psychology, 28(4): 318-326. https://doi.org/10.1016/j.jenvp.2008.03.003

Fornell, C. \& Larcker, D.F., 1981. Evaluating structural equation models with unobservable variables and measurement error. Journal of marketing research, 39-50. http://www.jstor.org/stable/3151312

Gast, J., Gundolf, K., \& Cesinger, B. (2017). Doing business in a green way: A systematic review of the ecological sustainability entrepreneurship literature and future research directions. Journal of Cleaner Production, 147, 44-56. https://doi.org/10.1016/j.jclepro.2017.01.065

Guagnano, G.A., 2001. Altruism and market-like behavior: An analysis of willingness to pay for recycled paper products. Population and Environment, 22(4): 425-438. http://www.jstor.org/stable/27503756

Guagnano, G.A., Stern, P.C. \& Dietz, T., 1995. Influences on attitude-behavior relationships: A natural experiment with curbside recycling. Environment and behavior, 27(5): 699-718. https://doi.org/10.1177/0013916595275005

Gubik, A. S., \& Farkas, S. (2016). Student entrepreneurship in Hungary: Selected results based on GUESSS Survey. Entrepreneurial Business and Economics Review, 4(4), 123-139. https://doi.org/10.15678/EBER.2016.040408

Hair F. Jr, J., Sarstedt, M., Hopkins, L. \& G. Kuppelwieser, V., 2014. Partial least squares structural equation modeling (PLS-SEM) An emerging tool in business research. European Business Review, 26(2): 106-121. https://doi.org/10.1108/EBR-10-2013-0128 


\section{ENTREPRENEURSHIP AND SUSTAIN \\ The International Journal}

ISSN 2345-0282 (online) http://jssidoi.org/jesi/ 2018 Volume 6 Number 2 (December) http://doi.org/10.9770/jesi.2018.6.2(4)

Han, H. \& Kim, Y., 2010. An investigation of green hotel customers' decision formation: Developing an extended model of the theory of planned behavior. International Journal of Hospitality Management, 29(4): 659-668. https://doi.org/10.1016/j.ijhm.2010.01.001

Han, H. \& Ryu, K., 2012. The theory of repurchase decision-making (TRD): Identifying the critical factors in the post-purchase decisionmaking process. International Journal of Hospitality Management, 31(3): 786-797. https://doi.org/10.1016/j.ijhm.2011.09.015

Han, H., Hsu, L.T.J. \& Sheu, C., 2010. Application of the theory of planned behavior to green hotel choice: Testing the effect of environmental friendly activities. Tourism management, 31(3): 325-334. https://doi.org/10.1016/j.tourman.2009.03.013

Hayes, A.F., 2013. Introduction to mediation, moderation, and conditional process analysis: A regression-based approach. Guilford Press.

Hayton, J.C., George, G. \& Zahra, S.A., 2002. National culture and entrepreneurship: A review of behavioral research. Entrepreneurship theory and practice, 26(4): 33-43. https://doi.org/10.1177/104225870202600403

Hill, M., Lowrance, C., Mulder, I., Boucher, J. \& Green, J., 2011. Embedding environmental risks in finance: Current methods and ongoing challenges. Journal of Environmental Investing, 2(1): 36-51. http://www.thejei.com/vol-2-no-1-2011/

Hofstede, G., 1991. Organizations and cultures: Software of the mind. McGrawHill, New York.

Holmgren, C. \& From, J., 2005. Taylorism of the mind: entrepreneurship education from a perspective of educational research. European Educational Research Journal, 4(4): 382-390. http://journals.sagepub.com/toc/eera/4/4

Iglesias-Sánchez, P. P., Jambrino-Maldonado, C., Velasco, A. P., \& Kokash, H. (2016). Impact of entrepreneurship programmes on university students. Education+ Training, 58(2), 209-228. https://doi.org/10.1108/ET-01-2015-0004

Janmaimool, P., 2017. Application of Protection Motivation Theory to Investigate Sustainable Waste Management Behaviors. Sustainability, 9(7): 1079-1090. https://doi.org/10.3390/su9071079

Jöreskog, K.G. \& Sörbom, D., 2006. LISREL 8.80 for Windows [Computer software]. Lincolnwood, IL: Scientific Software International.

Kaiser, F.G. \& Scheuthle, H., 2003. Two challenges to a moral extension of the theory of planned behavior: moral norms and just world beliefs in conservationism. Personality and Individual Differences, 35(5): 1033-1048. https://doi.org/10.1016/S0191-8869(02)00316-1

Kalafatis, S.P., Pollard, M., East, R. \& Tsogas, M.H., 1999. Green marketing and Ajzen's theory of planned behaviour: a cross-market examination. Journal of consumer marketing, 16(5): 441-460. https://doi.org/10.1108/07363769910289550

Kaplan, D. 2000. Structural Equation Modeling. Foundations and Extensions. Thousand Oaks London New Delhi: Sage Publications.

Keijzers, G., 2002. The transition to the sustainable enterprise. Journal of Cleaner Production, 10(4): 349-359. https://doi.org/10.1016/S0959-6526(01)00051-8

Kim, Y. \& Han, H., 2010. Intention to pay conventional-hotel prices at a green hotel-a modification of the theory of planned behavior. Journal of Sustainable Tourism, 18(8): 997-1014. ttps://doi.org/10.1080/09669582.2010.490300

Kim, Y., \& Choi, S.M., 2005. Antecedents of green purchase behavior: An examination of collectivism, environmental concern and PCE. Advances in Consumer Research, 32: 592-599. http://www.acrwebsite.org/volumes/9156/volumes/v32/NA-32

Koe, W.L. \& Majid, I.A., 2014. A Model for predicting intention towards sustainable entrepreneurship. International Journal of Information, Business and Management, 6(2): 256-270. https://ijibm.elitehall.com/index4.htm

Krueger, N.F., Reilly, M.D. \& Carsrud, A.L., 2000. Competing models of entrepreneurial intentions. Journal of business venturing, 15(5): 411-432. https://doi.org/10.1016/S0883-9026(98)00033-0

Laroche, M., Bergeron, J. \& Barbaro-Forleo, G., 2001. Targeting consumers who are willing to pay more for environmentally friendly products. Journal of consumer marketing, 18(6): 503-520. https://doi.org/10.1108/EUM0000000006155 


\section{The International Journal}

ENTREPRENEURSHIP AND SUSTAINABILITY ISSUES

ISSN 2345-0282 (online) http://jssidoi.org/jesi/

2018 Volume 6 Number 2 (December)

http://doi.org/10.9770/jesi.2018.6.2(4)

Law, M. M. S., Hills, P., \& Hau, B. C. H. (2017). Engaging Employees in Sustainable Development-a Case Study of Environmental Education and Awareness Training in Hong Kong. Business Strategy and the Environment, 26(1), 84-97. https://doi.org/10.1002/bse.1903

Leonidou, C. N., Skarmeas, D., \& Saridakis, C. (2018). Ethics, Sustainability, and Culture: A Review and Directions for Research. In Advances in Global Marketing (pp. 471-517). Springer, Cham. https://doi.org/10.1007/978-3-319-61385-7_19

Liñán, F., Battistelli, A. \& Moriano, J. A., 2008. Entrepreneurial Intentions in Europe. In J. A. Moriano, M. Gorgievski and M. Lukes (Eds.), Teaching psychology of entrepreneurship: Perspectives from six European countries (pp. 21-44), UNED, Madrid. ISBN: 978-84362-5568-3

Liñán, F., Nabi, G. \& Krueger, N., 2013. British and Spanish entrepreneurial intentions: A comparative study. Revista de economía Mundial, (33). 73-103.

Ling-Yee, L., 1997. Effect of collectivist orientation and ecological attitude on actual environmental commitment: The moderating role of consumer demographics and product involvement. Journal of international consumer marketing,9(4): 31-53. https://doi.org/10.1300/J046v09n04_03

Luszczynska, A., Gutiérrez-Doña, B. \& Schwarzer, R., 2005. General self-efficacy in various domains of human functioning: Evidence from five countries. International journal of Psychology, 40(2): 80-89. https://doi.org/10.1080/00207590444000041

Marsden, T. \& Smith, E., 2005. Ecological entrepreneurship: sustainable development in local communities through quality food production and local branding. Geoforum, 36(4): 440-451. https://doi.org/10.1016/j.geoforum.2004.07.008

Mbebeb, F.E., 2012. Building Ecological Entrepreneurship: Creating Environmental Solutions Based on the Cultural Realities and Needs of Local People. Journal of Environmental Investing, 3(2), 43-57. http://www.thejei.com/vol-3-no-2-2012/

McCarty, J.A. \& Shrum, L.J., 2001. The influence of individualism, collectivism, and locus of control on environmental beliefs and behavior. Journal of Public Policy and Marketing, 20(1): 93-104. http://www.jstor.org/stable/30000648

McCormick, M.J., Tanguma, J. \& López-Forment, A.S., 2002. Extending self-efficacy theory to leadership: A review and empirical test. Journal of Leadership Education, 1(2): 34-49. https://doi.org/10.12806/V1/I2/TF1

Meek, W.R., Pacheco, D.F. \& York, J.G., 2010. The impact of social norms on entrepreneurial action: Evidence from the environmental entrepreneurship context. Journal of Business Venturing, 25(5): 493-509. https://doi.org/10.1016/j.jbusvent.2009.09.007

Miller, D. (2015). A downside to the entrepreneurial personality? Entrepreneurship Theory and Practice, 39(1), 1-8. https://doi.org//10.1111/etap.12130

Momodu, A.S., Akinbami, C.A.O. \& Obisanya, J.F., 2011. Achieving food security and climate change mitigation through entrepreneurship development in rural Nigeria: Gender perspective. African Journal of Environmental Science and Technology, 5(10): 834-854. https://www.ajol.info/index.php/ajest/issue/view/8640

Moriano, J.A., Gorgievski, M., Laguna, M., Stephan, U. \& Zarafshani, K., 2012. A cross-cultural approach to understanding entrepreneurial intention. Journal of career development, 39(2):162-185. https://doi.org/10.1177/0894845310384481

Muñoz, P., \& Cohen, B. (2018). Sustainable entrepreneurship research: taking stock and looking ahead. Business Strategy and the Environment. 27, 300-322. https://doi.org/10.1002/bse.2000

Muñoz, P., \& Dimov, D. (2015). The call of the whole in understanding the development of sustainable ventures. Journal of Business Venturing, 30(4), 632-654. https://doi.org/10.1016/j.jbusvent.2014.07.012

Nunnally, J.C., 1978. Psychometric theory. Mc Graw-Hill Publ Co. New York.

Oliver, R.L., 1997. Satisfaction a behavioural perspective on the consumer. Irwin/MacGraw Hill. 


\section{The International Journal}

ENTREPRENEURSHIP AND SUSTAINABILITY ISSUES

ISSN 2345-0282 (online) http://jssidoi.org/jesi/

2018 Volume 6 Number 2 (December)

http://doi.org/10.9770/jesi.2018.6.2(4)

Outsios, G., \& Kittler, M. (2017). The mindset of UK environmental entrepreneurs: A habitus perspective. International Small Business Journal, 36(3), 285-306. https://doi.org/10.1177/0266242617739343

Ozaralli, N. \& Rivenburgh, N.K., 2016. Entrepreneurial intention: antecedents to entrepreneurial behavior in the USA and Turkey. Journal of Global Entrepreneurship Research, 6(1): 3-12. https://doi.org/10.1186/s40497-016-0047-x

Pastakia, A., 2002. Assessing Ecopreneurship in the context of a developing country. Greener Management International, 38(16), 93-108. https://doi.org/10.9774/GLEAF.3062.2002.su.00010

Pearlmutter, S., 1998. Self-efficacy and organizational change leadership. Administration in Social Work, 22(3): 23-38. https://doi.org/10.1300/J147v22n03_02

Pfajfar, G., \& Mitręga, M. (2016, July). Global dynamic capabilities revitalized-a novel approach and future research directions. In 2016 Global Marketing Conference at Hong Kong (pp. 995-997).

Ryu, K. \& Han, H., 2010. Predicting tourists' intention to try local cuisine using a modified theory of reasoned action: The case of New Orleans. Journal of travel and tourism marketing, 27(5): 491-506. https://doi.org/10.1080/10548408.2010.499061

Sardianou, E., Kostakis, I., Mitoula, R., Gkaragkani, V., Lalioti, E., \& Theodoropoulou, E. (2016). Understanding the entrepreneurs' behavioural intentions towards sustainable tourism: a case study from Greece. Environment, development and sustainability, 18(3), 857879. https://doi.org/10.1007/s10668-015-9681-7

Schaltegger, S., 2002. A Framework for Ecopreneurship. Greener Management International, (38): 45-58

Schaper, M. (2016). Understanding the green entrepreneur. In Making Ecopreneurs (pp. 27-40). Routledge.

https://people.ucsc.edu/ rlipsch/migrated/EE80S/Ecopreneur.pdf

Schultz, P.W. \& Zelezny, L., 1999. Values as predictors of environmental attitudes: Evidence for consistency across 14 countries. Journal of environmental psychology, 19(3): 255-265. https://doi.org/10.1006/jevp.1999.0129

Schwartz, S.H., 1977. Normative influences on altruism. Advances in experimental social psychology, 10, $221-279$. https://doi.org/10.1016/S0065-2601(08)60358-5

Stern, P.C. \& Dietz, T., 1994. The value basis of environmental concern. Journal of social issues, 50(3): 65-84. https://doi.org/10.1111/j.1540-4560.1994.tb02420.x

Stern, P.C., Dietz, T. \& Kalof, L., 1993. Value orientations, gender, and environmental concern. Environment and behavior, 25(5): 322348. http://dx.doi.org/10.1177/0013916593255002

Stern, S., 2006. Economic experiments: The role of entrepreneurship in economic prosperity. Melbourne Review: A Journal of Business and Public Policy, 2(2): 53-56. https://doi.org/10.1080/23322039.2018.1442093

Tandoh-Offin, P., 2009. A review of environmental entrepreneurship as an agenda for rural development: The case for Ghana. Journal of African Studies and Development, 2(2): 27-34. https://doi.org/10.2139/ssrn.1520669

Tascioglu, M., Eastman, J. K., \& Iyer, R. (2017). The impact of the motivation for status on consumers' perceptions of retailer sustainability: the moderating impact of collectivism and materialism. Journal of Consumer Marketing, 34(4), 292-305. https://doi.org/10.1108/JCM-03-2015-1351

Testa, S., \& Frascheri, S. (2015). Learning by failing: What we can learn from un-successful entrepreneurship education. The International Journal of Management Education, 13(1), 11-22. https://doi.org/10.1016/j.ijme.2014.11.001

Tilley, F. \& Parrish, B.D., 2009. Introduction. Greener Management International. Greenleaf Publishing, 5-11 
Tilley, F. \& Young, W., 2009. Sustainability Entrepreneurs. Greener Management International, (55): 79-92.

https://doi.org/10.9774/GLEAF.3062.2006.au.00008

Tilley, F., 1999. The gap between the environmental attitudes and the environmental behaviour of small firms. Business strategy and the environment, 8(4): 238-248. https://doi.org/10.1002/(SICI)1099-0836(199907/08)8:43.0.CO;2-M

Triandis, H.C., 1995. Individualism and Collectivism. Boulder, San Francisco.

Tzschentke, N.A., Kirk, D. \& Lynch, P.A., 2008. Going green: Decisional factors in small hospitality operations. International Journal of Hospitality Management, 27(1): 126-133. https://doi.org/10.1016/j.ijhm.2007.07.010

United Nations Organisation. 2011. "Treat Farmers like Entrepreneurs to Boost Creation of Wealth, Jobs, Urges Delegate as Second Committee Concludes Debate on Agriculture Development, Food Security." Sixty-sixth General Assembly. Accessed February 5, 2011. Available from http://www.un.org/News/Press/docs/2011/gaef3318.doc.htm

Valdez-Juárez, L. E., García-Pérez-de-Lema, D., \& Maldonado-Guzmán, G. (2018). ICT and KM, Drivers of Innovation and Profitability in SMEs. Journal of Information \& Knowledge Management, 17(01), 1850007-1-1850007-34. https://doi.org/10.1142/S0219649218500077

Vermeir, I. \& Verbeke, W., 2008. Sustainable food consumption among young adults in Belgium: Theory of planned behaviour and the role of confidence and values. Ecological economics, 64(3): 542-553. https://doi.org/10.1016/j.ecolecon.2007.03.007

Verplanken, B. \& Holland, R.W., 2002. Motivated decision making: effects of activation and self-centrality of values on choices and behavior. Journal of personality and social psychology, 82(3): 434-447. https://doi.org/10.1037/0022-3514.82.3.434

Wilson, F., Kickul, J. \& Marlino, D., 2007. Gender, entrepreneurial self-efficacy, and entrepreneurial career intentions: implications for entrepreneurship education. Entrepreneurship theory and practice, 31(3): 387-406. https://doi.org/10.1111/j.1540-6520.2007.00179.x

Winer, B.J., Brown, D.R. \& Michels, K.M., 1971. Statistical principles in experimental design (Vol. 2). New York: McGraw-Hill.

Yamaguchi, S., 1994. Collectivism among the Japanese: A perspective from the self. In U. Kim, H. C. Triandis, C. Kagitcibasi, S. C. Choi, and G. Yoon (Eds.), Individualism and collectivism (pp. 175-188). Newbury Park, CA: Sage.

Young, S., 2010. Turning Green into Green: Social Past, Financial Future. Journal of Environmental Investing, 1(2): 7-28. http://www.thejei.com/vol-1-no-2-2010/ 
The International Journal

ENTREPRENEURSHIP AND SUSTAINABILITY ISSUES

ISSN 2345-0282 (online) http://jssidoi.org/jesi/

2018 Volume 6 Number 2 (December)

http://doi.org/10.9770/jesi.2018.6.2(4)

Farida SALEEM, PhD is a Professor of Management in the department of Lahore Business School Gujrat Campus at The University of Lahore. She has more than 15 years of teaching and research experience at the university level. She is also serve as Director Academics of Gujrat Campus, The University of Lahore. Her research interest includes leadership, knowledge management, and team innovation.

ORCID ID: https://orcid.org/0000-0001-8022-2911

Ahmad ADEEL, PhD is an assistant professor of Management in the department of Lahore Business School Gujrat Campus at The University of Lahore. He has more than 8 years of banking experiences at managerial level and more than 3 years of teaching and research experience at the university level. His research interest includes: leadership, informal networks, and employee creativity.

ORCID ID: https://orcid.org/0000-0002-1853-9982

Rizwan ALI, PhD is an assistant professor of finance in the department of Lahore Business School at The University of Lahore. He has more than 8 years of teaching and research experience at the university level. His research interest includes corporate finance, corporate governance, and corporate social responsibility. ORCID ID: https://orcid.org/0000-0002-4439-6815

Shabir HYDER, PhD is an assiatnt professor in the deparment of Management Sciences, COMSATS, Attock. His research interest includes, small business migration, international business and projet management.

ORCID ID: https://orcid.org/0000-0001-6027-2401

Register for an ORCID ID:

https://orcid.org/register

Copyright (C) 2018 by author(s) and VsI Entrepreneurship and Sustainability Center

This work is licensed under the Creative Commons Attribution International License (CC BY).

http://creativecommons.org/licenses/by/4.0/

C) (i) Open Access 